Redefining Eclecticism in Early Modern Bolognese Painting 
A forum for innovative research on the role of images and objects in the late medieval and early modern periods, Visual and Material Culture, 1300-1700 publishes monographs and essay collections that combine rigorous investigation with critical inquiry to present new narratives on a wide range of topics, from traditional arts to seemingly ordinary things. Recognizing the fluidity of images, objects, and ideas, this series fosters cross-cultural as well as multi-disciplinary exploration. We consider proposals from across the spectrum of analytic approaches and methodologies.

\section{Series Editor}

Dr. Allison Levy, an art historian, has written and/or edited three scholarly books, and she has been the recipient of numerous grants and awards, from the National Endowment for the Humanities, the American Association of University Women, the Getty Research Institute, the Dumbarton Oaks Research Library of Harvard University, the Whiting Foundation and the Bogliasco Foundation, among others. www.allisonlevy.com. 


\section{Redefining Eclecticism in Early Modern Bolognese Painting}

Ideology, Practice, and Criticism

Daniel M. Unger 
This book is published with the support of the Israel Science Foundation.

Cover illustration: Guido Reni, Alliance between Disegno and Colore, 1620/5, Louvre, Paris (Photo: (C) Author).

Cover design: Coördesign, Leiden

Lay-out: Newgen/Konvertus

ISBN $\quad 9789462986015$

e-ISBN $\quad 9789048537259$

DOI $\quad 10.5117 / 9789462986015$

NUR $\quad 685$

(C) D.M. Unger/ Amsterdam University Press B.V., Amsterdam 2019

All rights reserved. Without limiting the rights under copyright reserved above, no part of this book may be reproduced, stored in or introduced into a retrieval system, or transmitted, in any form or by any means (electronic, mechanical, photocopying, recording or otherwise) without the written permission of both the copyright owner and the author of the book.

Every effort has been made to obtain permission to use all copyrighted illustrations reproduced in this book. Nonetheless, whosoever believes to have rights to this material is advised to contact the publisher. 
For Dina 
